\title{
Distribution of Bitter Crab Syndrome in Tanner crabs (Chionoecetes bairdi, C. opilio) from the Gulf of Alaska and the Bering Sea
}

\author{
T. R. Meyers ${ }^{1, *}$, J. F. Morado ${ }^{2}$, A. K. Sparks ${ }^{2}$, G. H. Bishop ${ }^{3}$, T. Pearson ${ }^{4}$, D. Urban ${ }^{4}$, \\ D. Jackson ${ }^{4}$
}

\begin{abstract}
'Alaska Department of Fish and Game, Commercial Fisheries Management and Development Division, Fish Pathology Section, PO Box 25526, Juneau, Alaska 99802-5526, USA

${ }^{2}$ National Oceanic and Atmospheric Administration, National Marine Fisheries Service, Resource Assessment and Conservation Engineering Division, Alaska Fisheries Science Center, 7600 Sand Point Way Northeast, Seattle, Washington 98115, USA

${ }^{3}$ The National Park Service, Glacier National Park, Gustavus, Alaska 99826, USA

${ }^{4}$ Alaska Department of Fish and Game, Commercial Fisheries Management and Development Division, 211 Mission Road, Kodiak, Alaska 99615, USA
\end{abstract}

\begin{abstract}
During 1988 to 1991, sampling efforts were conducted to determine prevalences of Bitter Crab Syndrome (BCS) in Tanner crabs from the Gulf of Alaska, the Bering Sea and the boundary area of the Chukchi Sea and Arctic Ocean. Stained hemolymph smears indicated that prevalences of BCS in Chionoecetes bairdi from the Gulf of Alaska were zero to $7.2 \%$ in Prince William Sound, zero in Cook lnlet and reached 3.6\% in the coastal waters of Kodiak Island. From there, prevalences declined southwesterly to $1.3 \%$ and zero along the Alaska Peninsula and the eastern Aleutian Islands. In the Bering Sea, the trend consisted of fluctuating low prevalences of BCS that increased by northerly latitudes in C. opilio, reaching the highest levels of 14.6 to $29.1 \%$ in Norton Sound and 13.3 to $15.5 \%$ in the Chukchi Sea/Arctic Ocean boundary area. The prevalences in C. bairdi from the eastern/northeastern Bering Sea were between zero and $2.4 \%$. Prevalences of BCS from Russian waters in the western Bering Sea ranged from 0.9 and $1.1 \%$ in $C$. bairdi and C. opilio, respectively. Sample stations where equally large numbers of both Tanner crab species were examined suggested little difference in parasite prevalences.
\end{abstract}

KEY WORDS: Tanner crab - Dinoflagellates $\cdot$ BCS

\section{INTRODUCTION}

Bitter Crab Syndrome (BCS) is caused by a parasitic dinoflagellate first observed from Tanner crabs Chionoecetes bairdi in southeast Alaska, USA in 1985 (Meyers et al. 1987). Subsequently, the disease has been found in at least $1 / 3$ of the commercial fishing areas managed by the Alaska Department of Fish and Game (ADF\&G) in southeast Alaska, with parasite prevalences reaching 95 to $99 \%$ in upper Lynn Canal (Meyers et al. 1990, Eaton et al. 1991). The mortality

•E-mail: fishpath\%fishgame@state.ak.us rate of parasitized crabs is $100 \%$; clinical signs of infection are: lethargy, excessive pink carapace pigmentation and white opaque hemolymph containing vast numbers of the causative agent. Meats from severely parasitized crabs are bitter tasting and unmarketable but harmless for human consumption. Field and laboratory data (Meyers 1990, Eaton et al. 1991, Love et al. 1993) suggest that the life cycle of the parasite spans a 16 to 18 mo period involving replicating trophont or vegetative stages that produce biflagellated microspores and macrospores.

The natural route of transmission for the $\mathrm{BCS}$ dinoflagellate has not been established by laboratory studies but the high prevalences of the parasite in 
some crab populations suggest a very efficient mechanism for infection. Speculation published in the literature has included the following possibilities for such transmission. The vegetative form, released from crabs dying from the disease or excreted with the urine and feces (Meyers et al. 1987), may infect other crabs that have aggregated for molting, either passively through breaks in the newly formed cuticle or by cannibalism of infected crabs. Field data have indicated that significantly greater prevalences of the parasite are found in newly molted crabs (Meyers et al. 1990, Eaton et al. 1991), but there is little overlap with molting in the spring and peak spore production in August and September (Meyers et al. 1987, Love et al. 1993). Hence, the role of the spores, if not infectious, is enigmatic unlcss they overwinter in the sediments and infect crabs later through detritus feeding or at the time of molting (Meyers et al. 1990). Histologic materials of infected Chionoecetes bairdi from a previously published study (Meyers et al. 1987) were re-examined to determine if the gametes of male crabs were a potential source of parasite transmission that had been overlooked. These observations (unpubl. data) are discussed later in this report.

Concern about the northernmost Chionoecetes bairdi populations and reports of excessive commercial holding losses of $C$. opilio that coincided with the onset of clinical signs of BCS in Alaskan Tanner crabs prompted extension of parasite distribution studies to the Gulf of Alaska and Bering Sea. Preliminary studies indicated that a dinoflagellate similar or identical to the BCS agent was present in the hemolymph smears of clinically affected crabs (Meyers 1990, Meyers et al. 1990, Pearson \& Meyers 1991). In this study we report the prevalence and distribution of the BCS dinoflagellate in one or both Tanner crab species from the waters of Prince William Sound, Cook Inlet, Kodiak Island, the Alaska Peninsula and eastern Aleutian Islands, the eastern and western Bering Sea, Norton Sound and the boundary area of the Chukchi Sea and Arctic Ocean during all or some of the years from 1988 to 1991 . Additional statistical comparisons of carapace width and shell conditions in parasitized and nonparasitized Tanner crabs of both sexes will be presented elsewhere in a separate report.

\section{MATERIALS AND METHODS}

Bering Sea: east, west and north. Our distribution study of BCS was conducted from 1988 to 1991 during the survey for both groundfish and crab resources that has been done annually during the June through September period for several years in the eastern Bering Sea by the Alaska Fisheries Science Center of the National Marine Fisheries Service (NMFS). Each survey was bounded on the west by the continental slope and the US-Russia Convention Line and generally did not proceed beyond latitude $62^{\circ} \mathrm{N}$. This zone encompassed 3 general areas (I, II, III), each containing 400 square nautical mile grids that resulted in about 375 stations sampled each year of the survey (Fig. 1).

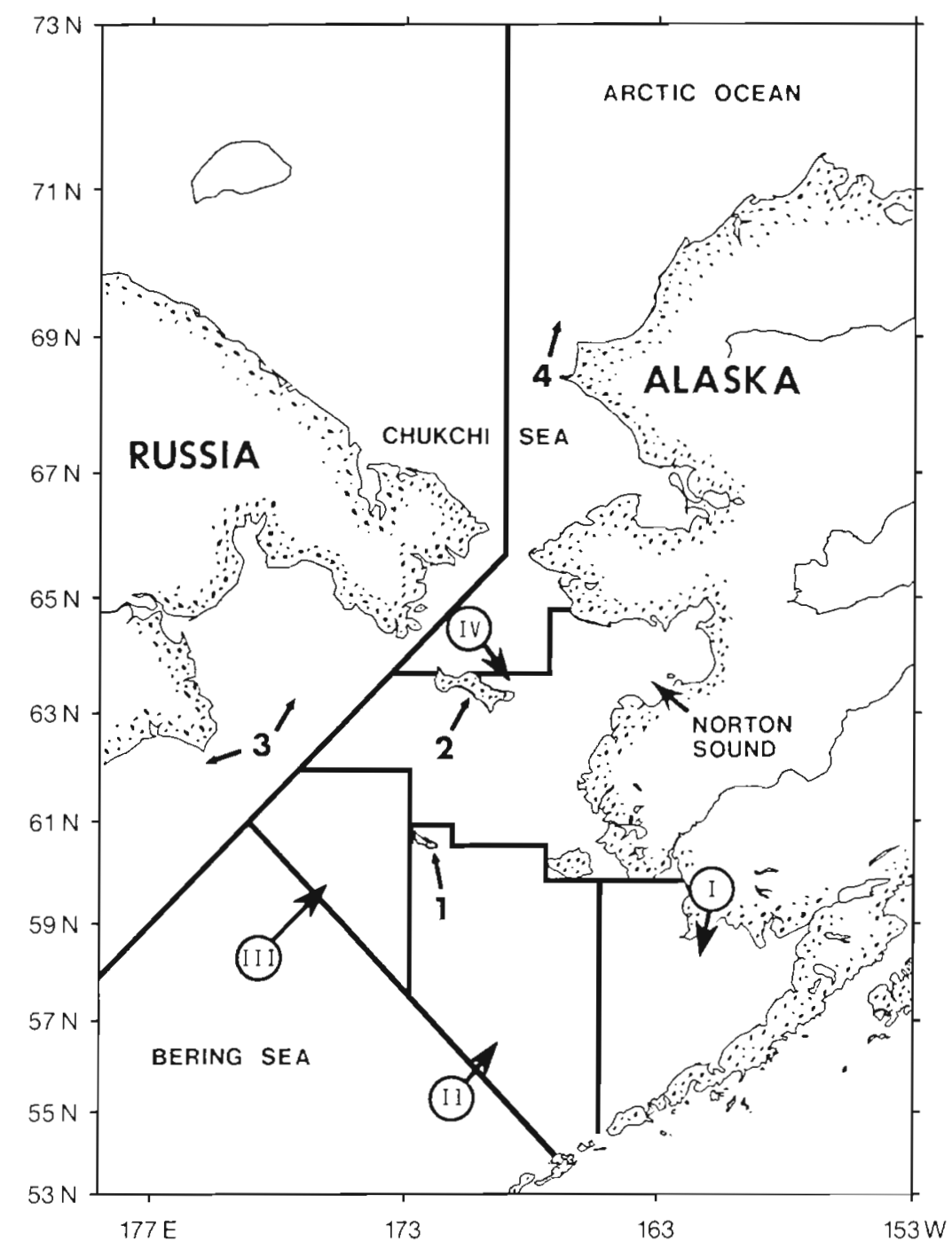

Fig. 1. Geographic zones in the Bering Sea and contiguous waters that were sampled during 1988 to 1991 for Bitter Crab Syndrome (BCS) in Chzonoecetes bairdi and C. opilio; Bristol Bay (I), the eastern (II, III, IV) and western Bering Sea (3), Norton Sound and the Chukchi Sea/Arctic Ocean boundary area near Point Hope (4). (1) St. Matthew Island; (2) St. Lawrence Island 
Fig. 2. Geographic zones in the Gulf of Alaska that were sampled during 1990 and 1991 for BCS in Chionoecetes bairdi. Zone $A$, from west to northeast, includes the eastern Aleutian Islands ( 1 to 5 ), Alaska Peninsula from Morzhovoi Bay (6) to Cape Douglas (8), Kodiak Island (7) and Cook Inlet (9). (1a) Pribilof Islands; (1) Umnak Island; (2) Unalaska Island; (3) Akutan Island; (4) Akun Island; (5) Unimak Island Zone $B$ is Prince William Sound including Port Fidalgo (10) and Montague Island (11)

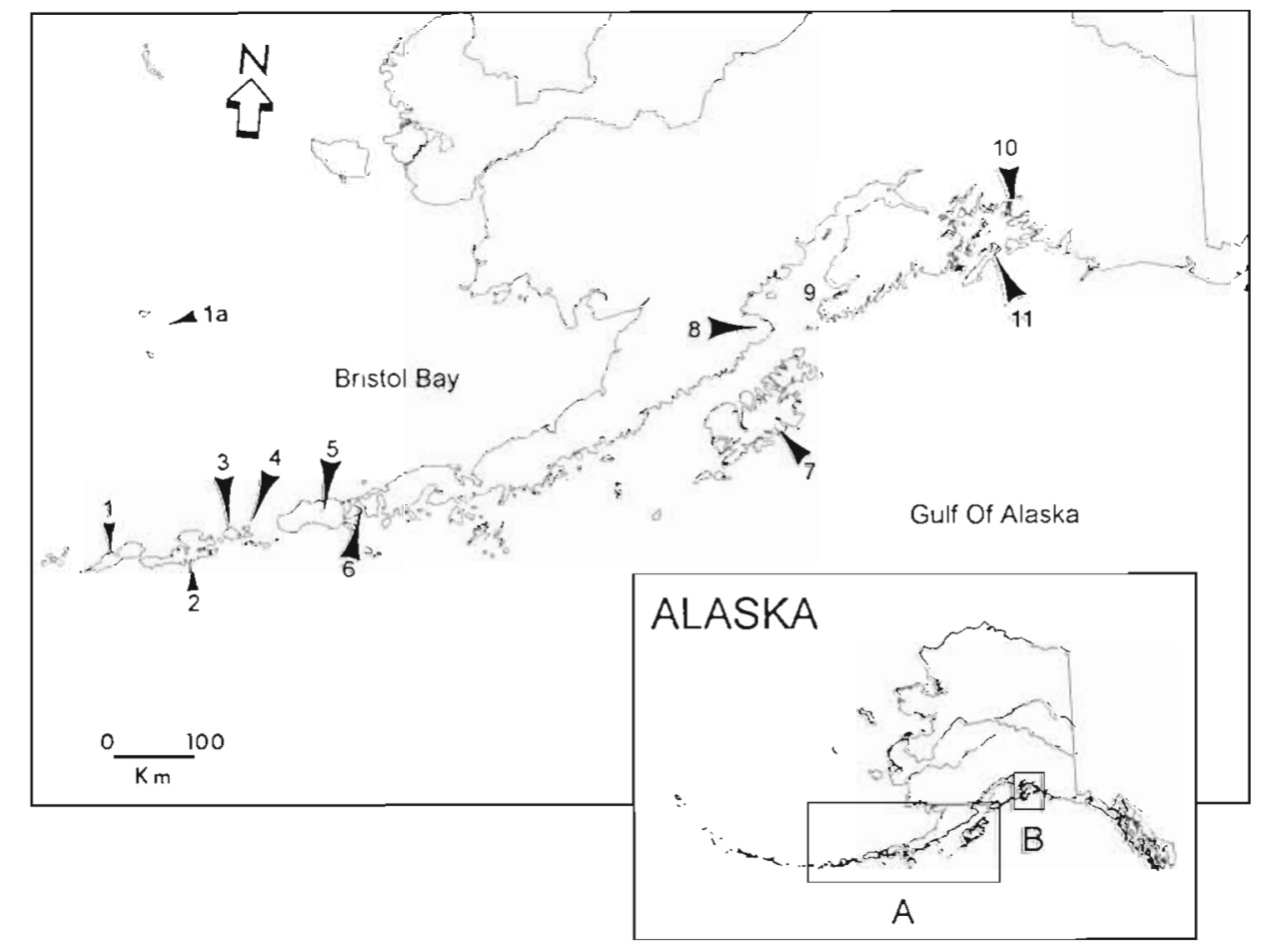

Each station was sampled in the center of its square mile grid, except for the grids immediately south of the Pribilof and St. Matthew Islands (Figs. 1 \& 2). Additional sampling was conducted at the corners of these sites to increase the accuracy and precision of stock assessment for the Alaskan blue king crab Paralithodes platypus. Tanner crab collections were made with an 83-112 Eastern Bottom Trawl with 90 to $100 \mathrm{~mm}$ mesh towed at 3 knots for approximately $1.5 \mathrm{~km}$. The size of the net opening during the trawling period was about $2.5 \mathrm{~m}$ high and 14.5 to $17.5 \mathrm{~m}$ wide.

In 1988 and 1991 a fourth similarly sized area (IV). encompassing the northeast Bering Sea and Norton Sound, was included in the survey. In 1990 the western Bering Sea was sampled in a US-Russia cooperative groundfish survey. Also in 1990, the boundary waters where the Chukchi Sea and Arctic Ocean converge, beginning at Point Hope, were surveyed in a northeasterly direction in a collaborative venture with the University of Alaska. Earlier in 1989, small numbers of male Chionoecetes opilio (see Table 2) were collected from that same general area using commercial crabpots (Meyers et al. 1990) after $25 \mathrm{~h}$ of bottom time at a depth of about $39 \mathrm{~m}$.

Approximately $50 \%$ of the Bering Sea stations in the known distribution ranges of both Chionoecetes bairdi and C. opilio (Areas I, II, III) were randomly selected for sampling beforehand since general station positions for each survey were known. Hemolymph smears were prepared by NMFS personnel from Tanner crabs at each of the randomly selected stations only when the numbers of crabs were equal to or greater than 10 . If more than 10 crabs were collected, 10 to 20 (sometimes more) were randomly selected for hemolymph smears from the total catch at each station. The most abundant Tanner crab species was selected for BCS examination when both crab species were caught at the same selected station. As an estimate of the accuracy of gross observation, hemolymph smears were prepared from 63 crabs suspected of having BCS, but these data were excluded from the random overall prevalence data. All hemolymph smears were later stained and examined (Meyers et al. 1987) in the ADF\&G fish pathology lab. Tissues from at least 5 of the 10 crabs selected at each station were preserved in $10 \%$ buffered formalin for histological examination by NMFS pathologists to compare with hemolymph smears for accuracy in detecting BCS. Because hemolymph smears were found to be as accurate as histology (Morado \& Sparks unpubl.) and more easily prepared, less emphasis was given to the collection of tissues for histopathology in 1990 and 1991

Gulf of Alaska. For several years an annual groundfish survey has been conducted by the ADF\&G during June through September, encompassing about 525000 square miles including Kodiak Island, the Alaska Peninsula and eastern Aleutian Islands (Fig. 2). In 1990 the prevalence of BCS in Chionoecetes bairdi was examined in waters producing most of the commercial catch surrounding Kodiak Island and along the 
Alaska Peninsula from Cape Douglas to Morzhovoi Bay and along the southern shores of the eastern Aleutian Islands of Unimak, Akun, Akutan, Unalaska and Umnak (Fig. 2). Crabs were collected at each station in a bottom trawl using methods described by Urban (1992). From each of 423 tows, 3 to 5 crabs were randomly selected for hemolymph smears as described previously. All other crabs were examined visually for gross clinical signs of BCS. Hemolymph smears made from 278 crabs suspected to have BCS were examined to determine the accuracy of gross examination.

Earlier, in 1988 and 1989, small numbers of male Chionoecetes opilio and C. bairdi crabs were collected by commercial crab pots fished in about $40 \mathrm{~m}$ of water in the manner described from several different areas in the castcrn Boring Sca including near the Pribilof and eastern Aleutian Islands (Figs. 1 \& 2).

In 1990 and 1991, a similar use of commercial crab pots resulted in collection of Chionoecetes bairdi from 1 site in Cook Inlet and 5 stations in Prince William Sound from the northern end of Montague Island to Port Fidalgo (Fig. 2).

\section{RESULTS}

The first samples from the eastern/northeastern Bering Sea (Table 1) in 1988 were only from Chionoecetes opilio and revealed a low level of BCS $7(2.2 \%)$ in the southeast areas (Area II), with an increase of prevalence in a northerly direction, particularly in Area IV (total $8.7 \%$ ) including those stations located southwest of St. Lawrence Island $(5.4 \%)$ and Norton Sound (14.6\%) (Table 2). In 1989, BCS was found in C. opilio from Area III (2.5\%) southwest of St. Matthews Island (northerly stations towards St. Lawrence Island were not done) but also to a slightly lesser degree in Area II stations $(1.2 \%)$. In 1989, C. bairdi were also collected in Area I with no BCS detected. Again in

Table 1. Prevalence of Bitter Crab Syndrome (BCS) in Chionoecetes bairdi (B) and C. opilio (O) Tanner crabs from sample areas I to IV in the eastern and northeastern Bering Sea including Norton Sound from 1988 to 1991. ND: not done

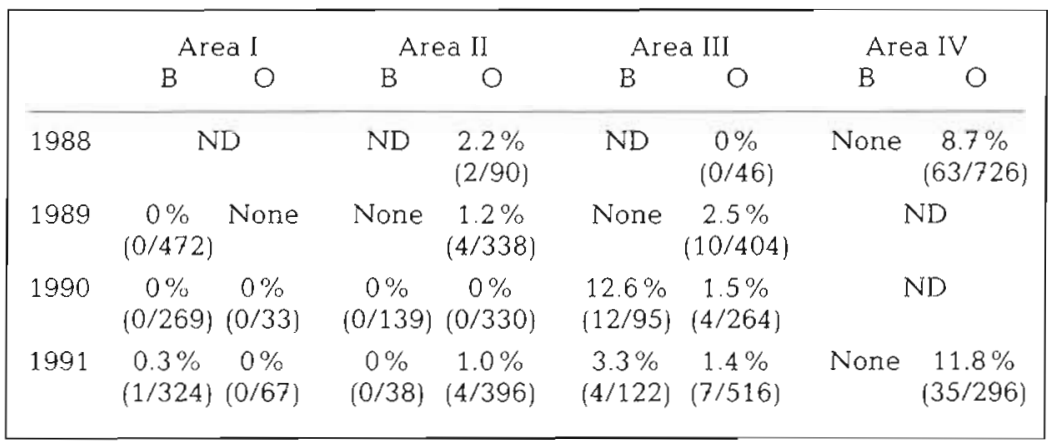

1990, the northerly Area III stations for both C. opilio and $C$. bairdi crabs were highest in prevalence $(1.5$ and $12.6 \%$, respectively) with no BCS detected in Areas I or II. In 1991, BCS prevalence again increased in the more northerly sample areas with $C$. bairdi having $0.3 \%$ in Area I and $3.3 \%$ in Area III. The prevalence in $C$. opilio increased from $1 \%$ in Area II to $11.8 \%$ in Area IV, much of this contributed by Norton Sound $(29.1 \%$ ) (Table 2). Overall, the prevalence of $\mathrm{BCS}$ in the eastern/northeastern Bering Sea, excluding Norton Sound, was highest in C. opilio in 1988 (3.2 to $4.9 \%$ ) (Table 2), dropping to $0.6 \%$ in 1990 and increasing again to $1.8 \%$ in 1991 . The prevalence in $C$. bairdi ranged from zero in 1989 to a high of $2.4 \%$ in 1990, dropping to $1 \%$ in 1991 (Table 2).

The trend of iñcreasing pievalence of BCS northward continued in the Chukchi Sea/Arctic Ocean boundary area where limited sampling of Chionoecetes opilio in 1989 showed $13.3 \%$ parasitized crabs The larger sample collected in 1990 had a similarly high prevalence of $15.5 \%$ (Table 2). No samples were taken in 1991.

The western Bering Sea in Russian waters, sampled for the first time in 1990, had overall low levels of BCS at 0.9 and $1.1 \%$ in Chionoecetes bairdi and C. opilio, respectively. Samples taken in 1991 yielded no $C$. bairdi but BCS was detected in $2.1 \%$ of the $C$. opilio examined (Table 2).

Southward in the Gulf of Alaska during the 1990 survey, $\mathrm{BCS}$ prevalence in Chionoecetes bairdi was $3.6 \%$ in the intensively fished coastal waters around Kodiak Island, declining southwesterly to $1.3 \%$ and zero in waters off the southern shores of the Alaska Peninsula and the eastern Aleutian Islands, respectively (Table 2). However, gross examination of larger numbers of crabs for clinical signs of BCS indicated very low parasite prevalences in all 3 areas that still declined in a southwesterly trend, with Kodiak Island again having the highest prevalence (Table 2). In the Kodiak Island district, the waters around the southwest shoreline (Alitak Bay) accounted for the majority of crabs infected by the BCS parasite for both blood smears $(15 / 81=18.5 \%)$ and gross examination $(152 / 5281=2.9 \%)$. Additional prevalence data for specific sample sites in the Gulf of Alaska are provided elsewhere (Pearson \& Meyers 1991).

The accuracy of gross identification of $\mathrm{BCS}$ ranged from $86 \%(54 / 63)$ to $98 \%(272 / 278)$ as indicated by the hemolymph smears examined from all suspect crabs. As expected, prevalences based on gross examination were conservative since crabs in the 

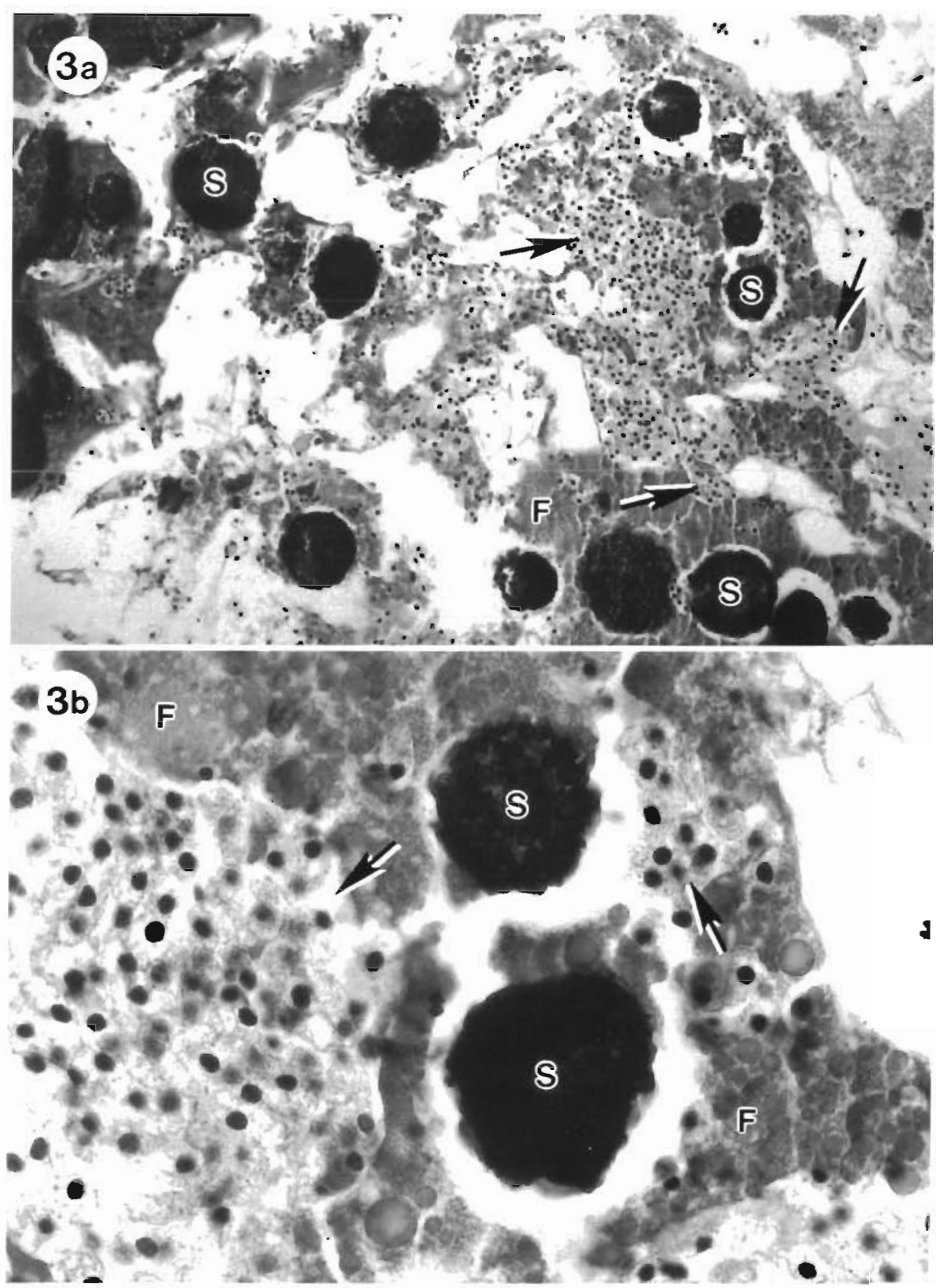

Fig. 3. Chionoecetes bairdi. Hematoxylin and eosin tissue section of the vas deferens from a male Tanner crab infected with the BCS dinoflagellate. (a) Vegetative stages of the parasite (arrows) within vacuoles of the seminal fluid $(F)$ surrounding the spermatophores $(\mathrm{S})_{i} \times 90$. (b) Greater detail of spermatophores and parasites in (a): $\times 350$

Canal. In these water bodies, crab populations may be less migratory, ocean currents less complex and the smaller areas could allow the parasite to become concentrated for more efficient dissemination among host crabs. A similar recycling analogy was proposed in the fjords of British Columbia for golden king crabs Lithodes aequispina parasitized by the rhizocephalan barnacle Briarosaccus callosus (Sloan 1984). Crab hosts confined to these narrow fjords by depth and sediment sills may have had more frequent contact with the infectious parasite larvae released from other infected crabs. This in turn could have resulted in the increased parasite prevalence observed within the confined crab population. This hypothesis may not explain the high prevalences of BCS in Norton Sound where the hydrologic features are apparently more complex. The Bering Sea, however, is an open ocean body with a relatively flat shallow bottom providing greater mixing, more crab migration or dispersal and less contact with the parasite. 
Bering Sea fishermen have not resorted to sorting out diseased crabs as has been practiced in the southeast fishery as a result of high prevalences there of BCS. Sorting for BCS has undoubtedly exacerbated the disease problem in certain districts of the southeast Alaska Tanner crab fishery where parasitized animals have been thrown back and apparently healthy crabs retained. Consequently, the return of obviously unmarketable crabs to the sites of capture has increased the prevalence of diseased crabs and the dissemination of BCS. Until alternative uses or practical disposal methods are devised for parasitized crabs, culling of Tanner crabs on the harvest grounds where prevalences of $\mathrm{BCS}$ are high is likely to continue. Equally important in parasite dissemination has been the transport of infected crabs to processing stations in other areas where whole crabs or raw parts have been discarded locally as unmarketable. This practice has been largely discontinued, but in some of these areas the disease has become detectable or has increased as a result.

Successful management of BCS, if attainable, will depend upon documenting the routes of parasite transmission and implementing precautions to help prevent the disease from increasing or spreading to healthy Tanner crab populations. Our re-examination of previously studied histological material (Meyers et al. 1987) indicated a potential route of parasite transmission (unpubl. data) that could be very important to the understanding of BCS. The vas deferens in a small number of naturally infected male crabs (4/7) revealed vegetative stages of the BCS parasite in vacuoles within the seminal fluid surrounding the spermatophores (Fig. 3a, b). As in the excretory system, parasite infiltration of the vas deferens is likely passive through boundary tissues that have degenerated from progression of the disease. Whether the presence of parasite cells in the vas deferens is evidence for sexual transmission with the transfer of spermatophores awaits further investigation. Nonetheless, the possibility is intriguing because 1 infected male crab may mate with several newly molted uninfected females. Although the ventral portion of the female genital canal (vagina) remains cuticularized during the molt, the dorsal secretory area of the spermatheca is glandular (Beninger et al. 1993) and relatively unprotected. Copulatory behavior is known to result in injury to female crabs (Watson 1972) which increases the likelihood of injury to the genital canal and parasite access to the female host circulatory system.

Several management options have been proposed that might be beneficial in controlling BCS in Alaska.
These have included moving the Tanner crab season to October/November when the disease is at an earlier stage of progression and infected crabs are still marketable (Meyers et al. 1990). If all crabs were marketable, there would be no need for sorting and discarding of infected individuals, thus reducing dissemination of the disease. This option and others should be investigated as soon as possible before further damage occurs to the Alaskan Tanner crab resources and additional economic losses are sustained due to BCS.

\section{LITERATURE CITED}

Beninger PG, Lanteigne C, Elner RW (1993) Reproductive processes revealed by spermatophore dehiscence experiments and by histology, ultrastructure, and histochemistry of the female reproductive system in the snow crab Chionoecetes opilio (O. Fabricius). J Crust Biol 13:1-16

Eaton WD, Love DC, Botelho C, Meyers TR, Imamura K Koeneman $T$ (1991) Preliminary results on the seasonality and life cycle of the parasitic dinoflagellate causing bitter crab disease in Alaskan Tanner crabs (Chionoecetes bairdi). J Invertebr Pathol 57:426-434

Hudson DA, Adlard RD (1996). Nucleotide sequence determination of the partial SSU rDNA gene and ITS1 region of Hematodinium of perezi and Hematodinium-like dinoflagellates. Dis Aquat Org 24:55-60

Love DC, Rice SD, Moles DA, Eaton WD (1993) Seasonal prevalence and intensity of bitter crab dinoflagellate infection and host mortality in Alaskan Tanner crabs Chionoecetes bairdi from Auke Bay, Alaska, USA. Dis Aquat Org $15: 1-7$

Meyers TR (1990) Diseases of crustacea: diseases due to protistans and metazoans. In: Kinne $O$ (ed) Diseases of marine animals, Vol III. Biologische Anstalt Helgoland, Hamburg

Meyers TR, Botelho C, Koeneman T, Short S, Imamura $K$ (1990) Distribution of bitter crab dinoflagellate syndrome in southeast Alaskan Tanner crabs Chionoecetes bairdi. Dis Aquat Org 9:37-43

Meyers TR, Koeneman T, Botelho C, Short S (1987) Bitter crab disease: a fatal dinoflagellate infection and marketing problem for Alaskan Tanner crabs Chionoecetes bairdi. Dis Aquat Org 3:195-216

Pearson T, Meyers TR (1991) Prevalence of BCS and bacterial infection of Tanner crab, Chionoecetes bairdi, in the Kodiak, Chignik, south Peninsula, and eastern Aleutian management districts. Reg. Information. Rpt, Commercial Fisheries Division, ADF\&G, Kodiak

Sloan NA (1984) Incidence and effects of parasitism by the rhizocephalan barnacle, Briarosaccus callosus Boschma. in the golden king crab, Lithodes aequispina Benedict, from deep fjords in northern British Columbia, Canada. J Exp Mar Biol Ecol 84:111-131

Urban D (1992) A bottom trawl survey of crab and groundfish in the Kodiak Island, Alaska Peninsula, and Dutch Harbor areas, June through September, 1990. Ak Dept Fish Game Tech Fish Rep 92-10, Juneau

Watson J (1972) Mating behavior in the spider crab, Chionoecetes opilio. J Fish Res Bd Can 29:447-449

Manuscript first received: October 5, 1995

Revised version accepted: February 21, 1996
Responsible Subject Editor: J. E. Stewart, Dartmouth, Nova Scotia, Canada 